Unsettling India 



\section{Unsettling India}

Affect, Temporality, Transnationality

PURNIMA MANKEKAR

Duke University Press Durham and London 2015 
(C) 2015 Duke University Press

All rights reserved

Printed in the United States of

America on acid-free paper $\infty$

Typeset in Chaparral Pro by

Westchester

Library of Congress Cataloging-in-

Publication Data

Mankekar, Purnima, 1961-

Unsettling India : affect, temporality,

transnationality / Purnima Mankekar.

pages $\mathrm{cm}$

Includes bibliographical references and index.

ISBN 978-o-8223-5822-o (hardcover : alk. paper)

ISBN 978-o-8223-5836-7 (pbk. : alk. paper)

1. East Indian diaspora.

2. East Indians-United States-Ethnic identity.

3. Mass media and culture. I. Title.

DS432.5.M28 2015

909'.04914-dc23

2014032513

ISBN 978-o-8223-7583-8 (e-book)

Cover art: Meera Sethi, Anamika

Sengupta (Ann), from the Foreign

Returned series. Courtesy of the artist. 
For Akhil, with love 
